\title{
Can Psychological Resilience Protect the Mental Health of Healthcare Professionals during the COVID-19 Pandemic Period?
}

\author{
Aynur Bahar ${ }^{a}$ Hatice Serap Koçak ${ }^{b}$ Sevgin Samancıoğlu Bağlamac \\ Döndü Çuhadar ${ }^{\mathrm{a}}$ \\ aPsychiatric Nursing Department, Health Sciences Faculty, Gaziantep University, Gaziantep, Turkey; \\ bPublic Health Nursing Department, Health Sciences Faculty, Gaziantep University, Gaziantep, Turkey; \\ 'Internal Medicine Nursing Department, Health Sciences Faculty, Gaziantep University, Gaziantep, Turkey
}

\section{Keywords}

Psychological resilience $\cdot$ Mental health $\cdot$ COVID-19

pandemic $\cdot$ Healthcare professionals

\begin{abstract}
It is important to protect the mental health of healthcare employees who are facing the difficult experience of a pandemic. There are proofs indicating that the state of mental wellbeing is related with the levels of psychological resilience. It may be important for reducing the psychological issues and emotions of burnout in healthcare professionals by increasing their psychological resilience levels during this process in which disease anxiety and fear of death develop. The purpose of this review study was to attract attention to the mental issues and psychological resilience of healthcare professionals who have the closest contact with the patients.
\end{abstract}

(C) 2020 The Author(s)

Published by S. Karger AG, Basel

\section{Introduction}

Following the reporting of pneumonia cases with unknown etiology in the city of Wuhan in the Hube state of China in December 2019, it was announced on January 7,
2020, that a new coronavirus (2019-nCoV; COVID-19) discovered for the first time in humans was the cause of these cases [1]. The implementation of quarantine was not started in China until January 23, 2020, and announcements were made late with regard to contagion among people or healthcare employees [2]. It was reported on January 30,2020, that the disease is observed in 18 countries worldwide [3]. The WHO stated that COVID-19 can be considered as a pandemic. During this period, it is as important to manage the mental health and psychosocial welfare as it is to manage physical health [4]. The negativities related with COVID-19 on healthcare employees, including the disease burden on the healthcare system, as well as the infection risk can be considered as the important effects of this global pandemic [5]. The COVID-19 outbreak forces health professionals around the world to make impossible decisions and work under extreme pressures. These decisions may include how to allocate inadequate resources equally to the patients, how to balance their own physical and mental healthcare needs with those of patients, how to align their desire and duty to patients with those to family and friends, and how to provide care for all severely unwell patients with limited or inadequate resources. This situation may cause healthcare workers to experience moral injury or mental

\begin{tabular}{ll}
\hline karger@karger.com & (c) 2020 The Author(s) \\
Pww.karger.com/dmj & Published by S. Karger AG, Basel \\
& This article is licensed under the Creative Commons Attribution- \\
Narger & NonCommercial-NoDerivatives 4.0 International License (CC BY- \\
NC-ND) (http://www.karger.com/Services/OpenAccessLicense). \\
Usage and distribution for commercial purposes as well as any dis- \\
tribution of modified material requires written permission.
\end{tabular}

Döndü Cuhadar

Department of Psychiatric Nursing, Faculty of Health Sciences Gaziantep University, University Boulevard

Şehitkamil, Gaziantep 27310 (Turkey)

donducuhadar@hotmail.com 
health problems [6]. It has been reported that at least 3,000 healthcare employees have been infected in China with at least 22 dead.

Based on the National Health Institute data, there are 6,414 healthcare employees with a positive COVID-19 test result as of March 24, Tuesday, in Italy with the highest death toll reported in Europe considered as the new base of the contagion and 51 doctors have died since the start of the pandemic [7]. Even though it is known that contagion takes place mostly by way of asymptomatic individuals, there are reports on various individuals who have passed on the disease to more than 1 family member [8]. In the epidemic process, healthcare workers are afraid of infecting their environment (family, friends, and colleagues), their anxiety increases due to the uncertainty they experience, and they are excluded and stigmatized due to the possibility of carrying the virus. While some of these fears and responses are based on real risks, many are due to lack of information, rumors, and misinformation. Because of these repercussions, healthcare professionals experience high levels of stress, anxiety, and depression. However, it should not be overlooked that these high stress, anxiety, and depression symptoms can cause longterm mental effects [9]. The whole world has been affected by the COVID-19 pandemic. The virus continues to affect all individuals and healthcare employees with increasing number of cases and deaths despite the fact that isolation precautions have been taken early on in the process. The purpose of this review study was to attract attention to the mental problems of healthcare employees in close contact with patients during the pandemic as well as the importance of psychological resilience throughout the period.

\section{Effects of Pandemic on Mental Health of Healthcare Professionals}

The psychological responses of healthcare employees against a contagion are complex. Sources of distress may include emotions of vulnerability or loss of control, health of the family or others due to the spreading of the virus, changes at the working conditions, and environment or isolation anxieties [10]. Healthcare workers who are directly involved in the diagnosis, treatment, and care of patients with COVID-19 are at a risk of developing psychological distress and other mental health symptoms. The increasing number of confirmed and suspected cases, overwhelming workload, lack of personal protection equipment, lack of specific drugs, and feelings of being inadequately supported may cause the mental problems of healthcare workers [11]. Anxieties related with mental health, psychological adaptation, and recovery may develop in healthcare employees providing treatment and care services to COVID-19 patients. It was put forth in a study in China on healthcare employees (doctors and nurses) treating COVID-19 patients that the mental health symptoms are quite high. In general, $50.4 \%$ of all participants reported symptoms of depression, $44.6 \%$ anxiety, $34.0 \%$ insomnia, and $71.5 \%$ psychological distress [9]. It was reported in a previous study carried out during the severe acute respiratory syndrome contagion that $89 \%$ of the healthcare employees under high risk displayed psychological symptoms [12]. In a meta-analysis study, it was found that nursing staff exhibited higher prevalence estimates both for anxiety and depression compared to doctors. These results attributed to the fact that they may face a greater risk of exposure to COVID-19 patients as they spend more time on wards, provide direct care to patients, and are responsible for the collection of sputum for virus detection. Also, it is stated that due to their closer contact with patients, they may be more exposed to moral injury pertaining to suffering, death, and ethical dilemma [13].

Hospitals are complex organizations with different and more intensive sources of stress than other workplaces due to their dynamic structure with intense human labor [14]. The US National Institute for Occupational Safety and Health classified the hazards and risks in the workplace as physical, chemical, biological, ergonomic, and psychological hazards and risks [15]. Healthcare employees are subject to many infections that may be spread by both the patients and other staff members which may lead to various diseases [16]. COVID-19 known to spread by way of droplets and droplet nuclei in the breathed air is considered as a major biological hazard for healthcare employees.

Cases that threaten the health of individuals which lead to intensive stress due to uncertainties affect the health of patients as well as healthcare employees [17]. The presence of psychosocial hazards is another issue for healthcare employees who may potentially contact the patients or tissue parts and infected medical tools including the infected air. Healthcare employees may also experience stress resulting from long and irregular work hours due to shift work, night duties, and calls for work in addition to $[18,19]$. Nursing staff are commonly exposed to shift work and long work hours. These demanding schedules can lead to difficulties such as misalignment of sleep with circadian rhythms that leads to difficulties with fall- 
ing asleep, more arousals during sleep, and early awakenings leading to poorer sleep quality and shorter sleep duration. Sleep deprivation reduces the ability to concentrate, reaction time, and the ability to remember and learn new facts and motor skills. This situation also leads to irritability, bad mood, reduced communication skills, and ability to cope with the emotional demands of the workplace. In addition, reduced situation awareness can impair a nurse's ability to respond to patient care needs [20]. The stress related with being directly responsible from providing care to patients with contagious and deadly health issues along with psychological problems such as fears and anxieties related with the possibility of being subject to COVID-19 coupled with occupational safety issues. Chronic insomnia, fatigue, memory and concentration disorders, injuries, malpractice, common chronic diseases, mood disorders, burnout syndrome, alienation, and domestic issues may be listed among the primary issues $[20,21]$. Providing sufficient personal protective equipment in order to prevent the inevitable damages at the workplace is another major issue that should be taken into consideration [22]. Personal protective equipment has become an important subject during the current coronavirus (COVID-19) epidemic. COVID-19 is predominantly caused by contact or droplet transmission. Contact, droplet, and airborne transmission are each relevant during airway maneuvers in infected patients, particularly during tracheal intubation. Personal protective equipment is an important component of a system protecting staff and other patients from COVID-19 cross-infection. Appropriate use significantly reduces the risk of viral transmission [23]. The greatest risk factor that employees are faced with during this pandemic is the lack of masks and other protective equipment. For this reason, healthcare employees in Italy have submitted posts through social media under the hashtag of \#GetMePPE requesting protective equipment such as masks, gowns, or face shields [24]. In addition, nurses have also announced that they are planning to go on strike due to lack of protective equipment as well as the difficult working conditions resulting from the spreading of the pandemic in the USA [25].

\section{Psychological Resilience}

Psychological resilience is defined as the process of adapting well in the face of adversity, trauma, tragedy or threats such as family and relationship problems, serious health problems, or workplace and financial stressors and involves the ability of the individual to bounce back from these difficult experiences or to overcome the transformations successfully $[26,27]$. The precondition for improving psychological resilience is the encounter of the individual with the risk factors. Protective factors should be present in order to reduce the impact of these negative factors or to eliminate them completely $[26,28]$. The potentially risky cases that individuals encounter during their professional lives and the protective factors they have affect their psychological resilience [29-31]. Psychological resilience is an important concept for the healthcare employees who are faced with many different risk factors during the COVID-19 pandemic process and who are obliged to provide professional healthcare services to the patients in need.

It has been put forth that psychological resilience is a personal characteristic comprising 3 subdimensions. These are self-commitment, control, and challenges. Selfcommitment refers to a sense of purpose and meaning with regard to taking an active part in daily events; control refers to the belief that one can affect the various situations in an individual's life rather than being negatively affected; and challenge expresses the belief of the individual in change [32]. These 3 characteristics change the perception of the individual with regard to the events and circumstances faced in life while reducing the impact of stress. The quality of life increases for individuals who are able to control stress $[32,33]$. Psychological resilience is the ability of the individual to cope with and overcome obstacles, uncertainties, and other similar circumstances [34]. In the promoting mental health report, the WHO has conceptualized mental health as personal characteristics, including the psychological sources of positive emotions, self-esteem, and sufficiency, as well as psychological resilience corresponding to the coping capacity with negativities [35].

According to the American Psychological Association, psychological resilience is the adaptation process of people against stress factors such as anxiety, depression, trauma, distressing event, and threat [36]. It is observed when the study results are examined that the psychological resilience levels of healthcare employees are high and that they develop psychological resilience as a result of the negativities they face at their workplaces [37-39]. A negative relationship was determined in another study between psychological factors and psychological resilience [39]. It has been put forth as a result of the studies that individuals with high psychological resilience experience mental disorders less [40, 41]. 


\section{Psychological Resilience in the Pandemic Process}

Psychological resilience is a developmental process encompassing what is perceived and learned when faced with truths [26]. Overcoming problems and the capacity to prevent mental health from deteriorating when faced with stress varies among individuals. Responses against stress may also serve as coping mechanisms [35]. Psychological resilience that increases the ability to struggle with and resist difficulties may enable healthcare employees to recover more easily after the pandemic. Individuals with a state of mental well-being are affected less from the results of the stresses they face and may be more successful in crisis management. Individuals with psychological resilience may easily overcome stressful situations through struggling, resistance, and displaying the proper behaviors.

The COVID-19 contagion that is continuing to spread results in stress and stressful conditions of life for people and societies. Disease-related fear and anxiety may be depressing and may lead to intensive emotions in both adults and children. Everyone may react differently to stressful situations. The impact of an emergency on an individual may be related with the characteristics and experiences of the individual [42]. The spread of infectious diseases is often prevented by isolation of populations at risk and quarantine. These approaches restrict the mobility, social interactions, and daily activities of the affected individuals. During a crisis like the COVID-19 outbreak, it is common for everyone to experience increasing levels of anxiety and anxiety as a result of social isolation [43]. Quarantine presents psychological difficulties for quarantined individuals, their relatives, and healthcare professionals who care for them [44]. Healthcare employees who have to work under quarantine conditions may face various mental difficulties. It has been reported in a study that stresses experienced during the COVID-19 outbreak result from long quarantine durations, fear of infection, frustration, boredom, insufficient materials, insufficient knowledge, financial loss, and stigmatization [45]. It was put forth in a study on the impact of quarantines due to severe acute respiratory syndrome which resembles the current outbreak that post-trauma stress symptoms are observed in hospital employees even 3 years after the outbreak [46], whereas it was indicated in another study examining $100 \%$ of the hospital staff members [1-50] with regard to depression symptoms 3 years after quarantine that $9 \%$ of the sample group expressed severe depressive symptoms [47]. Increased workload, physical exhaustion, inadequate personal equipment, nosocomial transmis- sion, and the need to make ethically difficult decisions on care may have negative effects on healthcare workers' physical and mental well-being. So, healthcare workers' resilience can be further compromised by isolation and loss of social support, risk or infections of friends and relatives, as well as drastic, often unsettling changes in the ways of working [13]. When all these are taken into consideration, it is observed that high psychological resilience levels are important for the healthcare employees to fight against COVID-19 infection effectively and to protect their mental health.

Organizations and individuals can develop cognitive, emotional, and interpersonal skills that foster adaptive coping responses and contribute to both an organizational and a personal resilience plan. Albott et al. [48] has summarized the stress responses to the COVID-19 pandemic and strategies for developing organizational and personal resilience (Table 1).

Interventions to enhance resilience can be administered before, during, or after stressful/traumatic situations. If interventions/training occurs prior to stressful events, the individual is better prepared to deal with adversity. Humans have great potential to change or adapt when necessary, but they need basic social and material resources to do so. One of the most important ways to strengthen resilience is to promote healthy family and community environments that allow the individual's natural protective systems to develop and work effectively [36].

\section{Conclusion}

Improvement of mental health includes attempts to reduce or eliminate factors with adverse impacts on mental health along with those related with improving the health state and resilience of individuals. Psychological resilience is the ability of the individual to adapt positively to distressing situations in their lives. Psychological resilience is possible through positive structuring of relations, continuing positivity, developing emotional insight, balancing professional and social life, and strengthening spirituality [49]. All these contribute to the development of the mental life of the society as well [50]. Cognitive restructuring methods, insight and getting to know one's own self, balancing professional and social life, strengthening personal objectives, going through experiences that may act as guides for future experiences, and developing problem-solving skills can be put forth as important applications for developing psychological re- 
Table 1. Psychological stress responses to the COVID-19 pandemic and preemptive strategies for building organizational and personal resilience (Albott et al. [48])

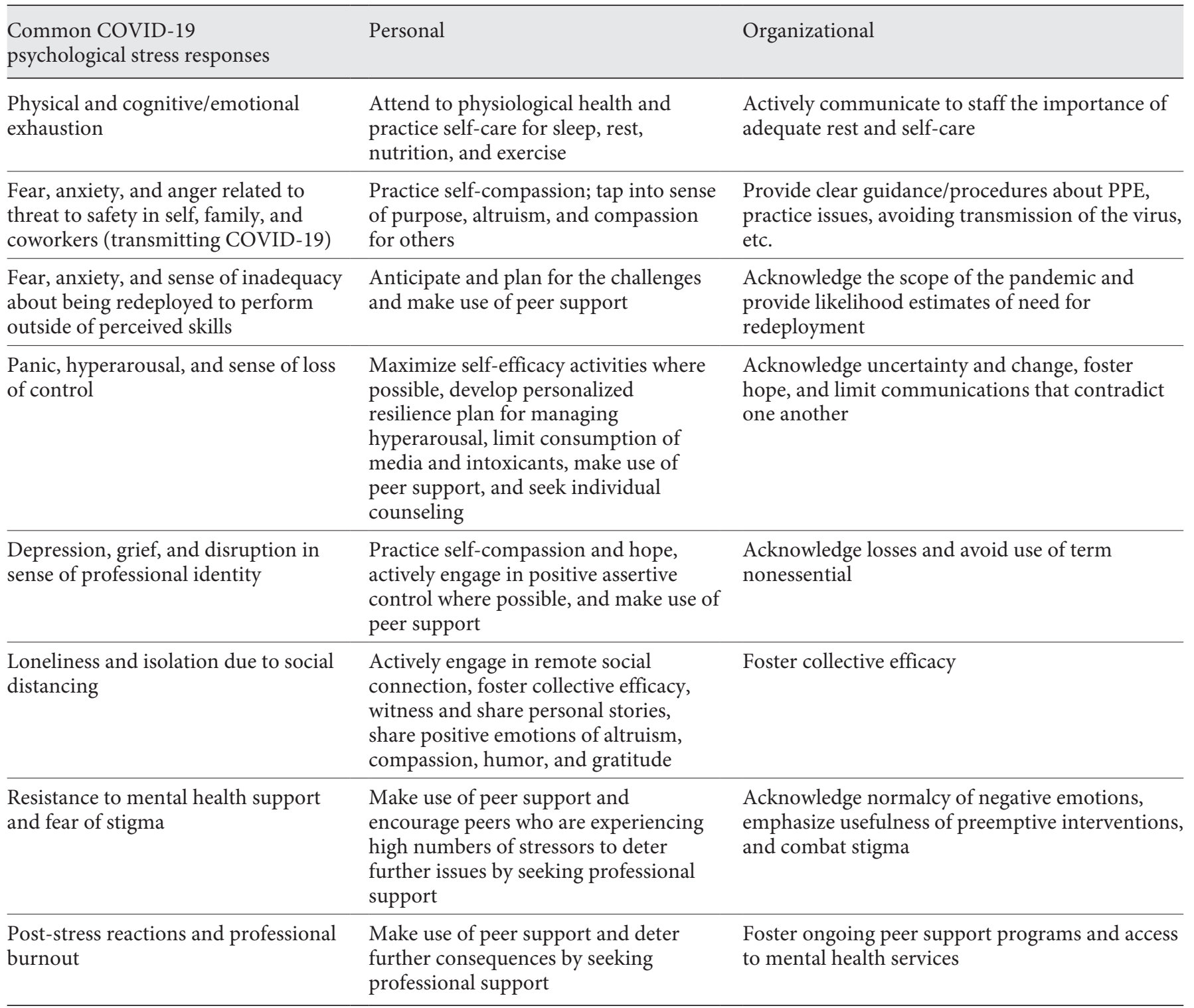

silience of healthcare employees at the personal level [49]. Mental support program for health professionals should be arranged as follows:

a. Collective psychoeducation

b. Collective relaxation activities

c. Group mental problem sharing

d. Individual problem sharing

e. Psychiatric evaluation and examination [9].

Things to do in order to develop personal skills to increase psychological resilience in healthcare professionals are as follows: establishing positive interpersonal rela- tionships, flexible thinking, critical and creative thinking, optimism, self-efficacy, altruism, using humor, protecting personal and professional moral boundaries, emotional intelligence, problem-solving, and coping [27]. In order to enhance psychological resilience among healthcare workers, interventions can be planned to clear communication, limitation of shift hours, provision of rest areas as well as broad access, and detailed rules on the use and management of protective equipment [13].

It is also important to carry out studies for examining the impact of the pandemic-related psychological pro- 
cesses on healthcare employees as well as the regulatory role played by psychological resilience during this process along with studies for determining the regulatory role of the variables. Moreover, it is predicted that implementing the approach for increasing psychological resilience will also protect the mental health of individuals against other risks that may develop.

\section{Conflict of Interest Statement}

The authors declare no conflicts of interests with respect to the authorship and/or publication of this article.

\section{Funding Sources}

None of the authors have obtained external funding anywhere. This study was funded by the authors themselves.

\section{Author Contributions}

All authors searched the literature and wrote the article. All authors reviewed the final manuscript before submitting for publication.

\section{References}

1 European Center for Disease Prevention and Control. Outbreak of acute respiratory syndrome associated with a novel coronavirus, Wuhan, China. First update 22 January 2020. [cited 2020 March 27]. Available from: https: //www.ecdc.europa.eu/sites/default/files/ documents/Risk-assessment-pneumoniaWuhan-China-22-Jan-2020.pdf.

2 Kavanagh MM. Authoritarianism, outbreaks, and information politics [cited 2020 March 27]. Available from: https://www.thelancet. com/journals/lanpub/article/PIIS24682667(20)30030-X/fulltext.

3 WHO. Novel Coronavirus (2019-nCoV) Situation Report: 10 [cited 2020 March 27]. Available from: https://www.who.int/docs/ default-source/coronaviruse/situationreports/20200130-sitrep-10-ncov.pdf? sfvrsn=d0b2e480_2.

4 WHO. Mental health and psychosocial considerations during the COVID-19 outbreak [cited 2020 March 27]. Available from: https: //www.who.int/docs/default-source/coronaviruse/mental-health-considerations.pdf.

5 Adams JG, Walls RM. Supporting the health care workforce during the COVID-19 global epidemic. JAMA. 2020 [Online ahead of print].

6 Greenberg N, Docherty M, Gnanapragasam S, Wessely S. Managing mental health challenges faced by healthcare workers during covid-19 pandemic. BMJ. 2020;368:m1211.

7 İtalya' da en az 51 doktor koronavirüs nedeniyle hayatını kaybetti. [Erişim tarihi 2020 April 15]. Available from: https://tr.euronews. com/2020/03/28/italya-da-en-az-51-doktorkoronavirus-nedeniyle-hayat-n-kaybetti.

8 Bai Y, Yao L, Wei T, Tian F, Jin D-Y, Chen L, et al. Presumed asymptomatic carrier transmission of COVID-19. JAMA. 2020;323(14): 1406-7.

9 Türk Psikiyatri Derneği [cited 2020 June 12]. Available from: https://www.psikiyatri.org. tr/TPDData/Uploads/files/COVID19_Pandemi_PsikiyatrikTedavilerTPDRTACB05052020.pdf.
10 Wong TW, Yau JK, Chan CL, Kwong RS, Ho SM, Lau CC, et al. The psychological impact of severe acute respiratory syndrome outbreak on healthcare workers in emergency departments and how they cope. Eur J Emerg Med. 2005;12(1):13-8.

11 Lai J, Ma S, Wang Y, Cai Z, Hu J, Wei N, et al Factors associated with mental health outcomes among health care workers exposed to coronavirus disease 2019. JAMA Netw Open. 2020;3(3):e203976.

12 Chua SE, Cheung V, Cheung C, McAlonan GM, Wong JW, Cheung EP, et al. Psychological effects of the SARS outbreak in Hong Kong on high-risk health care workers. Can J Psychiatry. 2004;49(6):391-3.

13 Pappa S, Ntella V, Giannakas T, Giannakoulis VG, Papoutsi E, Katsaounou P. Prevalence of depression, anxiety, and insomnia among healthcare workers during the COVID-19 pandemic: a systematic review and metaanalysis. Brain Behav Immun. 2020 Aug;88: 901-7.

14 Ülker N. Hastanede çalıșanların stres ve yönetimi. Balkan ve Yakın Doğu Sosyal Bilimler Dergisi. 2016:2(2):28-37.

15 Gürer A. Sağlık hizmetlerinde çalışan güvenliği. Johse. 2018;2(1):9-14.

16 Beșer A. Sağlık çalışanlarının sağlık riskleri ve yönetimi. DEUHYO ED. 2012;5(1):39-44.

17 Tel H, Karadağ M, Tel H, Aydın Ş. Sağlık çalışanlarının çalışma ortamındaki stres yaşantıları ile bașetme durumlarının belirlenmesi. Hemşirelikte Araştırma Geliștirme Dergisi. 2003;2:13-23.

18 Iacovides A, Fountoulakis KN, Kaprinis S, Kaprinis G. The relationship between job stress, burnout and clinical depression. J Affect Disord. 2003;75(3):209-21.

19 Meydanlığlu A. Sağlık çalışanlarının sağlı̆̆ı ve güvenliği. Balikesir Saglik Bil Derg. 2013; 2(3):192-9.

20 Caruso CC. Negative impacts of shiftwork and long work hours. Rehabil Nurs. 2014; 39(1):16-25.
21 Önder ÖR, Ağırbaș İ, Yenimahalleli G, Aksoy A. Ankara Numune Eğitim ve Araştırma Hastanesinde çalışan hekim ve hemşirelerin geçirdikleri iş kazaları ve meslek hastalıkları yönünden değerlendirilmesi. Ankara Sağlık Hizmetleri Dergisi. 2011;10:31-44.

22 İzgi MC, Türkmen HÖ. Akdeniz Üniversitesi'nde taşeron sağlık işçilerinin işçi sağlığı ve iş güvenliği durum tespiti. Türkiye Halk Sağlı̆̆1 Dergisi. 2012;10(3):160-73.

23 Cook TM. Personal protective equipment during the COVID-19 pandemic-a narrative review. Anaesthesia. 2020 Jul;75(7):920-7.

24 It feels like a war zone': doctors and nurses plead for masks on social media [cited 2020 April 15]. Available from: https://www.nytimes.com/2020/03/19/us/hospitals-coronavirus-ppe-shortage.html.

25 Thousands of nurses tired of working with too many patients will walk out of hospitals in a 4-state strike [cited 2020 April 15]. Available from: https: //www.businessinsider.com/ nurses-to-go-on-strike-for-better-patient-ratios-2019-9.

26 Basım HN, Cetin F. Yetişkinler için psikolojik dayanıklılık ölçeğinin güvenilirlik ve geçerlilik çalışması. Türk Psikiyatri Dergisi. 2011;22: 104-14.

27 Çam O, Büyükbayram A. Hemşirelerde psikolojik dayanıklılık ve etkileyen faktörler. Psikiyatri Hemșireliği Dergisi. 2017;8(2): 118-26.

28 Öz F, Bahadır Yılmaz E. Ruh sağlı̆̆ının korunmasında önemli bir kavram: psikolojik sağlamlık. Sağlık Bilimleri Fakültesi Hemşirelik Dergisi. 2009;16(3):82-9.

29 Mccann CM, Beddoe E, Mccormick K, Huggard P, Kedge S, Adamson C, et al. Resilience in the health professions: a review of recent literature. Int J Wellbeing. 2013;3(1):60-81.

30 Hart PL, Brannan JD, De Chesnay M. Resilience in nurses: an integrative review. J Nurs Manag. 2014;22(6):720-34. 
31 Matos PS, Neushotz LA, Griffin MT, Fitzpatrick JJ. An exploratory study of resilience and job satisfaction among psychiatric nurses working in inpatient units. Int J Ment Health Nurs. 2010;19(5):307-12.

32 Sezgin F. İlköğretim okulu öğretmenlerinin psikolojik dayanıklılık düzeylerinin incelenmesi. Kastamonu Eğitim Dergisi. 2012;20(2): 489-502.

33 Kavi E, Karakale B. Çalışan psikolojisi açısından psikolojik dayanıklılık. Emek ve Toplum. 2018;7(7):55-77.

34 Luthans F, Avey JB, Avolio BJ, Norman SM, Combs GM. Psychological capital development: toward a micro-intervention. J Organ Behav. 2006;27(3):387-93.

35 Taycan O,Coşkun B. Ruhsağlığınıgüçlendirme: kavramlar, kanitlar, uygulamalar: Özet Rapor. Türkiye Psikiyatri Derneği (2020). [Erișim tarihi 2020 March 29]. Available from: https:// apps.who.int/iris/bitstream/handle/10665/ 42940/9241591595-tur.pdf.

36 Southwick SM, Bonanno GA, Masten AS, Panter-Brick C, Yehuda R. Resilience definitions, theory, and challenges: interdisciplinary perspectives. Eur J Psychotraumatol. 2014;5(1):114-28.

37 Yalçın S. İlköğretim okulu öğretmenlerinin mesleki tükenmişlik düzeyleri ile stres, psikolojik dayanıklılık ve akademik iyimserlik arasındaki ilişki. Yayınlanmamış yüksek lisans tezi. Ankara: Gazi Üniversitesi Eğitim Bilimleri Enstitüsü; 2013.
38 Soysal MN. Facebook bağımlılığı ve psikolojik dayanıklılık. (Yayınlanmamıs yüksek lisans tezi). İstanbul: İstanbul Gelişim Üniversitesi Sosyal Bilimler Enstitüsü; 2016.

39 Cevizci O, Müezzin EE. Sağlık çalışanlarında psikolojik belirtilerin ve psikolojik dayanıklılığın incelenmesi. Kıbrıs Türk Psikiyatri ve Psikoloji Dergisi. 2019;1(3):166-72.

40 Hoge EA, Austin ED, Pollack MH. Resilience: research evidence and conceptual considerations for posttraumatic stress disorder. Depress Anxiety. 2007;24(2):139-52.

41 Kaba İ, Keklik İ. Öğrencilerin üniversite yaşamına uyumlarında psikolojik dayanıklılık ve psikolojik belirtiler. Hacettepe Eğitim Araştırmaları Dergisi. 2016;2(2):98-111.

42 Centers for Disease Control and Prevention, CDC [cited 2020 March 27]. Available from: http://www.cdc.gov/coronavirus/2019-ncov/ about/coping.html.

43 American Medical Association, AMA [Erişim tarihi 2020 May 15]. Available from: https://www.ama-assn.org/delivering-care/ public-health/managing-mental-health-during-covid-19.

44 Psychological effects of quarantine during the coronavirus outbreak: what healthcare providers need to know. Center for the Study of Traumatic Stress. [Erişim tarihi 2020 June 8]. Available from: https://www.cstsonline.org/ assets/media/documents/CSTS_FS_Psychological_Effects_Quarantine_During_Coronavirus_Outbreak_Providers.pdf.
45 Brooks SK, Webster RK, Smith LE, Woodland L, Wessely S, Greenberg N, et al. The psychological impact of quarantine and how to reduce it: rapid review of the evidence. Lancet. 2020;395(10227):912-20.

46 Wu P, Fang Y, Guan Z, Fan B, Kong J, Yao Z, et al. The psychological impact of the SARS epidemic on hospital employees in China: exposure, risk perception, and altruistic acceptance of risk. Can J Psychiatry. 2009;54(5): 302-11.

47 Liu X, Kakade M, Fuller CJ, Fan B, Fang Y, Kong J, et al. Depression after exposure to stressful events: lessons learned from the severe acute respiratory syndrome epidemic. Compr Psychiatry. 2012;53(1):15-23.

48 Albott CS, Wozniak JR, McGlinch BP, Wall MH, Gold BS, Vinogradov S. Battle buddies: rapid deployment of a psychological resilience intervention for health care workers during the coronavirus disease 2019 pandemic. Anesth Analg. 2020 [Online ahead of print].

49 Günüşen NP. Hemşirelerin ruh sağllğının korunması ve güçlendirilmesi. Turkiye Klinikleri J Psychiatr Nurs-special Top. 2017; $3(1): 12-8$.

50 Kirmayer LJ, Sheiner E, Geoffroy D. Mental health promotion for indigenous youth. 6 . Chapter. In: Hodes M, Gau S, editors. Positive mental health, fighting stigma and promoting resiliency for children and adolescents. Academic Press is an imprint of Elsevier; 2016. 